Review

\title{
Sustainable Underground Iron Ore Mining in Ukraine with Backfilling Worked-Out Area
}

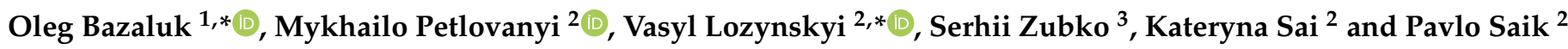 \\ 1 Belt and Road Initiative Centre for Chinese-European Studies, Guangdong University of Petrochemical \\ Technology, Maoming 525000, China \\ 2 Department of Mining Engineering and Education, Dnipro University of Technology, 49005 Dnipro, Ukraine; \\ petlyovany@ukr.net (M.P.); kateryna.sai@gmail.com (K.S.); saik.nmu@gmail.com (P.S.) \\ 3 PJSC Zaporizhzhia Iron-ore Plant, 69061 Zaporizhzhia, Ukraine; szubko1985@gmail.com \\ * Correspondence: bazaluk@ukr.net (O.B.); lvg.nmu@gmail.com (V.L.)
}

Citation: Bazaluk, O.; Petlovanyi, M.; Lozynskyi, V.; Zubko, S.; Sai, K.; Saik, P. Sustainable Underground Iron Ore Mining in Ukraine with Backfilling Worked-Out Area. Sustainability 2021, 13, 834. https://doi.org/10.3390/ su13020834

Received: 7 December 2020 Accepted: 13 January 2021 Published: 15 January 2021

Publisher's Note: MDPI stays neutral with regard to jurisdictional clai$\mathrm{ms}$ in published maps and institutional affiliations.

Copyright: (C) 2021 by the authors. Licensee MDPI, Basel, Switzerland. This article is an open access article distributed under the terms and conditions of the Creative Commons Attribution (CC BY) license (https:// creativecommons.org/licenses/by/ $4.0 /)$.

\begin{abstract}
The present paper considers aspects of underground iron ore mining in Ukraine, in particular the level of mine production and reserves of basic ore fields. It analyzes and generalizes the practice of using cemented rockfill under difficult mining and hydrogeological conditions of the Pivdenno-Bilozerske high-grade iron ore field. The Belozersky iron ore district is the only one in Ukraine that, without any technological cycle of beneficiation, can provide both domestic and foreign consumers with high-quality raw iron ore as required by world markets. The PJSC Zaporizhzhia iron ore plant extracts iron ore from the Pivdenno-Bilozerske field with an iron content of more than $60 \%$ using the low-waste, environmentally friendly technology of backfilling the mined-out area with a hardening mixture. The peculiarities of the technology for steep deposit mining and the main processes of backfilling operations in terms of preparation, transportation, and construction of the backfill mass with its stability assessment are explained in detail in this paper. As a result of using cemented rockfill, rock mass stability is provided, a considerable part of industrial waste is disposed of in the mined-out area, and the earth's surface subsidence within the area is prevented (in comparison with mining enterprises in other fields).
\end{abstract}

Keywords: iron ore; underground mining; backfill; deposit; Ukraine

\section{Introduction}

Ferrous metallurgy is widely developed in Ukraine, and the demand for iron ore is completely satisfied by its own reserves. Moreover, a significant part of commercial iron ore raw materials is exported to other countries. The largest export consumers of iron ore and concentrate in 2017 were China ( $27.8 \%$ of the total export of a commodity item in monetary terms), Slovakia (12.1\%), and Austria (11.3\%). Other countries exported $48.8 \%$. The specific volume of the commodity item of the total export volume in monetary terms is $5.9 \%$, which provides a high export potential $[1,2]$.

Mining and metallurgical complex (MMC) is the leading sector of the Ukrainian economy, and its sustainable development forms the main foreign exchange budget revenues (\$2.8 billion) [3], which is why providing sustainable mining in Ukraine is a critically important task nowadays [4,5]. A block of iron ore extraction, which is a raw material for ferrous metallurgy, is the first and important link in the chain of MMC functioning [6].

The world's iron ore reserves are estimated at 170 billion tons, while the iron content is 81 billion tons. Ukraine ranks fifth in the world among countries with iron ore reserves and seventh in terms of iron content (Figure 1) [1,7]. 


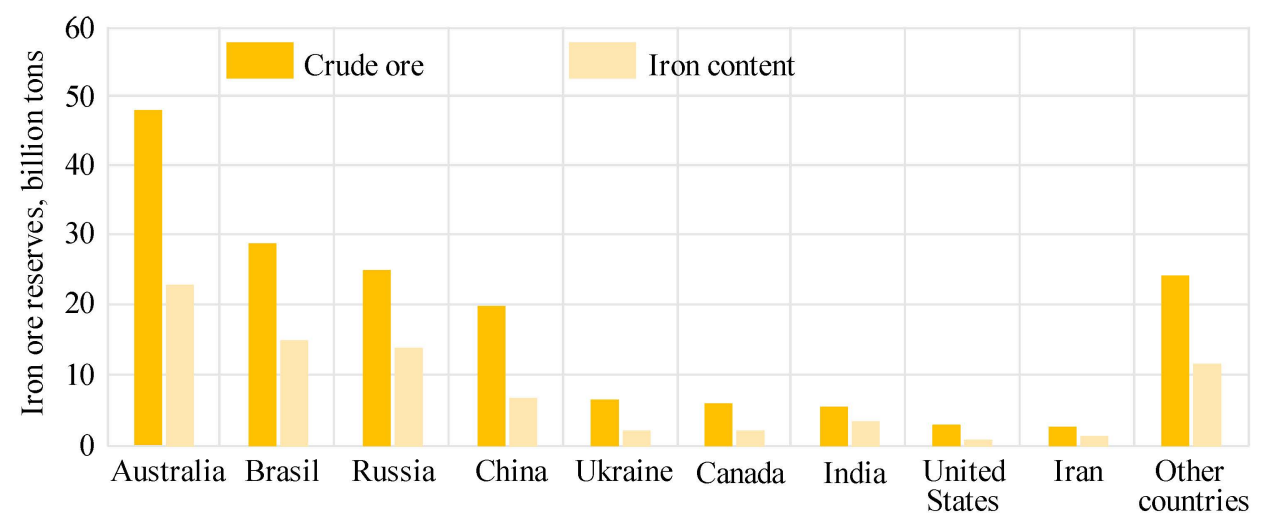

Figure 1. World iron ore reserves in leading countries (total geological reserves vs. iron content) $[1,7]$.

The annual iron ore output in Ukraine is approximately 160 million tons. Total explored reserves of iron ores are sufficient for mining enterprises to operate for 180 years, and the reserves of deposits under operation (or those operated until recently) are sufficient for 130 years. The methods of iron ore mining are as follows: open-pit mining is $90 \%$ and underground mining is $10 \%$. Nine mines annually extract almost 15 million tons of ore using the underground method [8-10].

Chamber mining (55\%) and sublevel caving (45\%) are the most popular methods for underground ore mining (Kryvyi Rih iron ore basin) [11,12]. However, chamber mining with cemented rockfill is also used at the PJSC Zaporizhzhia iron ore plant (Belozersky iron ore district), which makes it possible to achieve stability and a gradual increase in output over a long period of time. The dynamics of ore extraction at mining enterprises using the underground method is shown in Figure 2 [13].

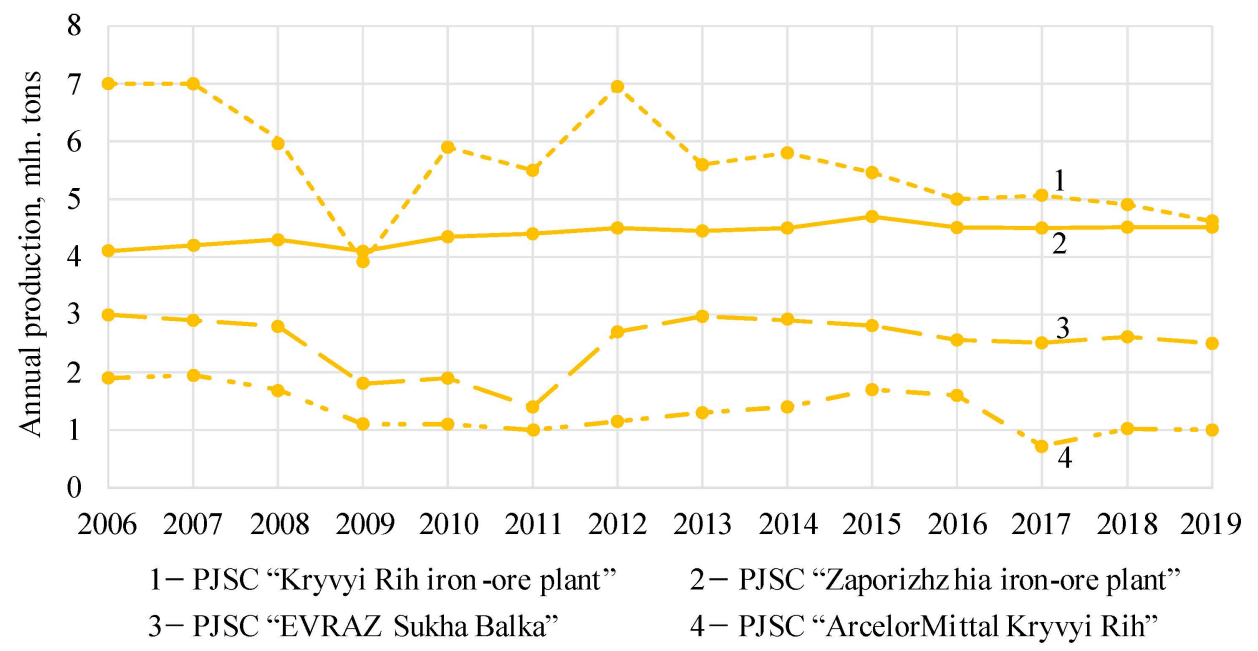

Figure 2. Dynamics of ore extraction by underground method at mining enterprises (2006-2019) [13].

The PJSC Zaporizhzhia iron ore plant is the only Ukrainian enterprise extracting highgrade iron ore without beneficiation cycle and with use of the low-waste, environmentally friendly method of backfilling the mined-out area with cemented rockfill [14-16]. This is a modern approach to develop economic and environmental strategies of underground mining [17].

When the caving system is used in the Kryvyi Rih iron ore basin, dilution is 9\% and ore losses are 16\% [18]. When cemented rockfill system is used, as at the PJSC Zaporizhzhia iron ore plant, it is possible to reduce dilution to $5 \%$ and the ore losses during mining operations to $8 \%[19,20]$.

As a result of the technological cycle of ore mining with backfilling at the PJSC Zaporizhzhia iron ore plant, the earth's surface subsidence has been prevented. On the contrary, 
in the Kryvyi Rih iron ore basin mines, which operate without backfilling, there have been numerous disturbances to the earth's surface with the formation of underground cavities and subsidence funnels (Figure 3).

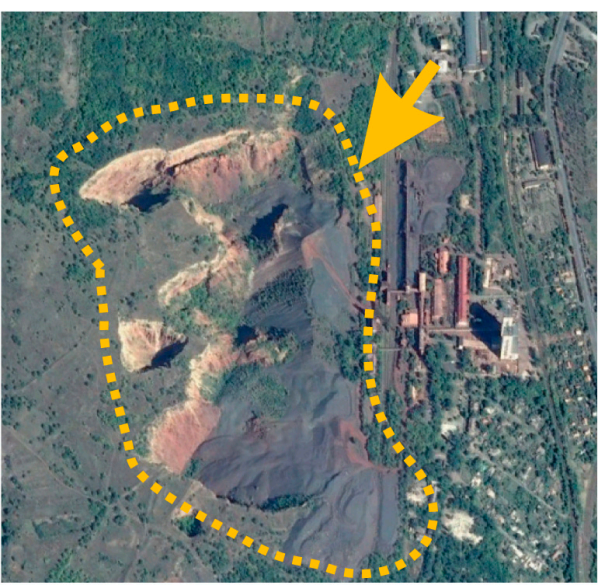

(a)

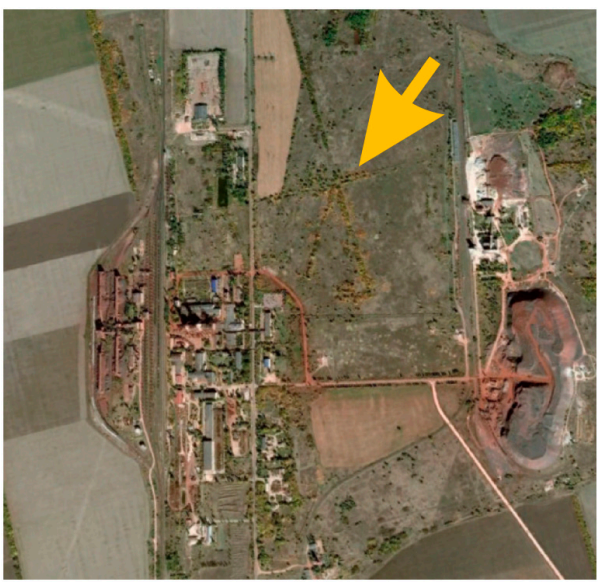

(b)

Figure 3. Earth's surface state within the mining allotment of iron ore mines: (a) ore mining without backfilling (PJSC Kryvyi Rih iron ore plant, Kryvyi Rih iron ore basin); (b) ore mining with backfilling using cemented rockfill (PJSC Zaporizhzhia iron ore plant, Belozersky iron ore field).

The problems of the earth's surface subsidence are observed in underground ore mining, especially when using block and sublevel caving mining methods [21]. It is essential to predict the subsidence as there is a risk of surface infrastructure destruction as well as economic damage to the mine [22].

The experience of mining ore deposits has shown a significant number of cases of the earth's surface subsidence. For example, at the Kiirunavaara mine (Sweden), a large-scale earth's surface subsidence occurred after the changeover to mining by the sublevel caving method. In addition, surface disturbances affected parts of the Kiruna city, the railway, and the power plant [23]. At the Ordzhonikidze iron mine (Ukraine), a large-scale earth's surface subsidence was noted on an area of 16 hectares, caused by large volumes of underground cavities as a result of using the chamber mining method by leaving the pillars, which led to critical consequences [24]. An incident of daylight surface subsidence occurred at the Maogong iron mine (China), where the sublevel caving method was used [25]. Furthermore, the earth's surface subsidence has been studied in detail for Anomaly No. 12 Sechahun (Iran) mining due to its impact on the important complex of surface infrastructure objects [26].

In most of the known cases of daylight surface deformations, the center of subsidence was in the hanging wall rocks of the ore deposit, although there have been certain cases of subsidence center formation in the footwall rocks [27]. It is possible to prevent the earth's surface subsidence by leaving the supporting ore pillars or backfilling the minedout area $[28,29]$.

As of 01.01.2019, according to the State Balance of Mineral Reserves in Ukraine, there were 60 iron ore fields, of which 29 were under development. The total balance reserves were 19,725.9 million tons for $\mathrm{A}+\mathrm{B}+\mathrm{C} 1$ and 7367.8 million tons $\mathrm{C} 2$; off-balance reserves was 4546.3 million tons [30].

The Kryvyi Rih iron ore basin (72\% of the proved reserves), Kremenchug iron ore region $(16 \%)$, Belozersky iron ore district $(10 \%)$, and Pryazovskyi iron ore region $(2 \%)$ are referred to as the Ukrainian Shield. Most of the deposits, including all those under development, are associated with ferruginous-siliceous formations of Archean and Proterozoic age. Iron ores are mined in Kryvyi Rih basin, Kremenchug and Belozersky iron ore regions [6,31,32]. The Pryazovskyi iron ore region is in the state reserve and is currently not in operation, while the Kerch iron ore basin is located on the territory of the occupied 
Autonomous Republic of Crimea. The spatial location of major iron ore basins, reserves, and iron content in the ore is shown in Figure 4.

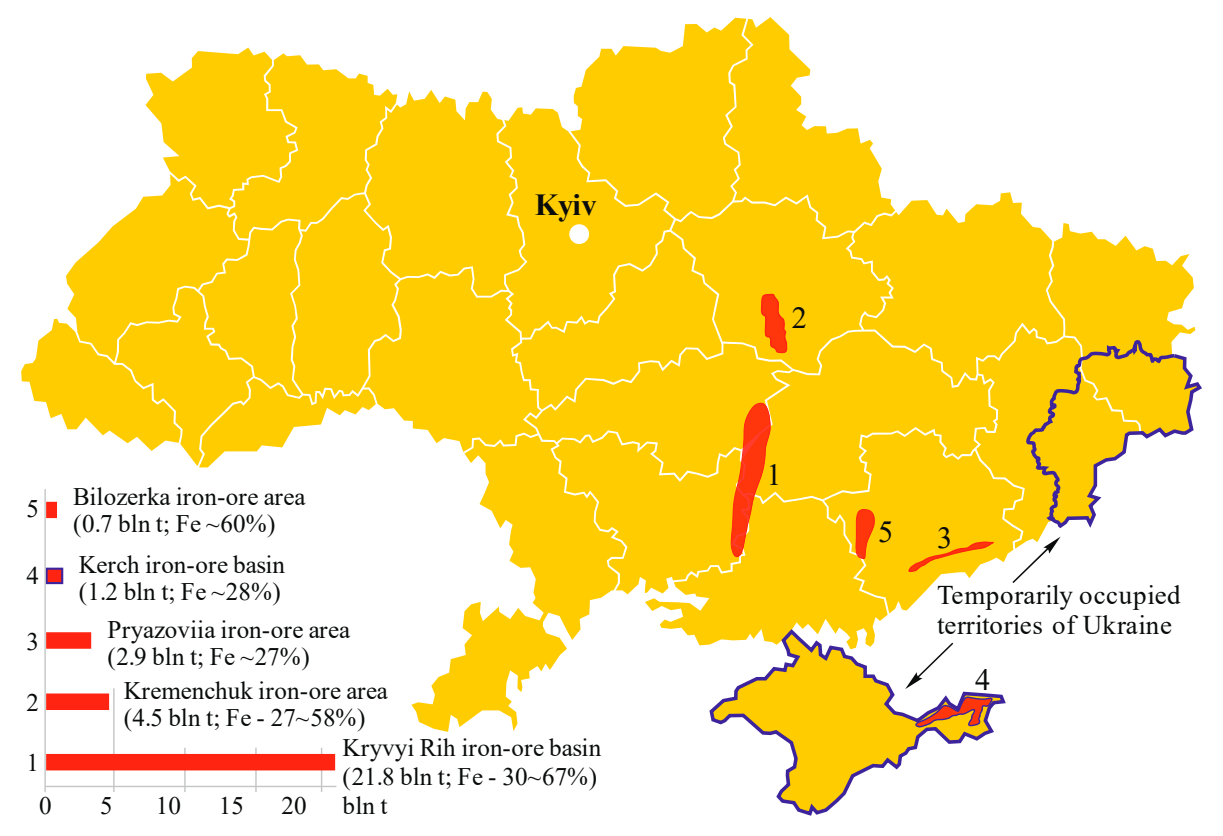

Figure 4. Major iron ore basins of Ukraine (spatial location, reserves, and content of iron).

It follows from Figure 4 that the Belozersky iron ore district with an iron content of more than $60 \%$ in ore is the only one in Ukraine that, without any technological cycle of beneficiation, can provide both domestic and foreign consumers with high-quality raw iron ore as required by world markets. The Belozersky iron ore district includes three iron ore deposits: Pivdenno-Bilozerske, Pivnichno-Bilozerske, and Pereverzivske. At present, only Pivdenno-Bilozerske is under development.

This paper analyzes and generalizes the practices of using cemented rockfill under difficult mining and hydrogeological conditions of the Pivdenno-Bilozerske high-grade iron ore deposit.

\section{Progressive Mining System of Backfilling Technology in the Pivdenno-Bilozerske Field}

\subsection{PJSC Zaporizhzhia Iron Ore Plant}

The Belozersky iron ore district is located on the territory of the Vasilyevsky and Veselovsky administrative districts in the Zaporizhzhia region and extends in the submeridial direction for $40 \mathrm{~km}$ from the Kakhovka Reservoir in the north and to the village of Vesele in the south. The area of the district is almost $1200 \mathrm{~km}^{2}$. The PJSC Zaporizhzhia iron ore plant develops the Pivdenno-Bilozerske field of high-grade iron ores with an iron content of more than $60 \%$. The field is represented by one thick steep vein and a number of lenticular veins adjacent to the neighboring field. The PJSC Zaporizhzhia iron ore plant is the only mining enterprise that uses a progressive system of mining of backfilling the mined-out area. This enterprise is the most representative object in Ukraine with long-term experience of thick deposit mining according to the specified mining system.

In 2004, a group of specialists from the PJSC Zaporizhzhia iron ore plant who were part of the writing team received the State Prize of Ukraine for the development and implementation of highly efficient environmentally friendly mining technology in difficult hydrogeological conditions.

\subsection{Peculiarities of Geology, Hydrogeology, and Tectonics}

High-grade hematite-martite ores of the Pivdenno-Bilozerske field ( $\mathrm{Fe}>60 \%$ ) occur in difficult mining and hydrogeological conditions, which are characterized by ore crystalline 
mass of aquifers in the roof as well as water cut of the ore crystalline mass, partial instability of the hanging wall rocks, and rock mass fracturing.

The length of the main ore body along the strike is $2.5 \mathrm{~km}$, and the ore reserves are mined to the dip to $1500 \mathrm{~m}$. The dip of ferruginous quartzite and ores is steep: northeastern and eastern at the southern end of the field and southeastern at the northern end. The slope angle increases from south $\left(60-65^{\circ}\right)$ to north $\left(80-85^{\circ}\right)$. The stability of hematite ores lengthwise is low and medium, and the fracturing is weak and medium with a hardness coefficient according to Professor M.M. Protodyakonov scale $[33,34]$ from $f=3-5$ to $f=6-8$. The deposit thickness varies from north to south (from 15 to $120 \mathrm{~m}$ ). The enclosing rocks of the hanging wall are represented by quartz-sericite and quartz-chlorite shale. They are characterized as mid- and coarse-interstratified and silicified rocks, with hardness coefficient according to Professor M.M. Protodyakonov scale of $f=6-9$ with medium fracturing and medium stability. The hanging wall of the ore body is represented by hematite-martite quartzite, mid to finely banded, sometimes folded with average stability, and with medium fracturing and medium stability $(f=14-15)$. Less frequently, they are represented by shale rocks (south end of the deposit) possessing the properties of stratification $[35,36]$.

The hydrogeological conditions of the Pivdenno-Bilozerske field are complex due to the occurrence of a thick stratum of sedimentary rock (up to $280 \mathrm{~m}$ ) above the ore deposits, containing eight aquifers and the water cut of the ore crystalline mass itself. According to the hydrogeological service data, the maximum predicted water inflows during the Pivdenno-Bilozerske field mining may be up to $2600 \mathrm{~m}^{3} / \mathrm{h}$. In the case of full-scale mining operations, it may be up to a horizon of $1240 \mathrm{~m}$.

A wide development of joints has been determined (both vertical and flat ones). The degree of vertical joints stretching prevail $350^{\circ}$, and the range of flat joint stretching is $250-275^{\circ}$. These joints divide ferruginous quartzite and ores into blocks. Moreover, they are complicated by folding of the fourth and higher order. No faults are observed in rocks and ores. The crystalline mass is heterogeneous in its physical and mechanical properties and is characterized by the presence of both monolithic and weathered zones with different hardness and stability. At the same time, the natural factors of different mineral deposit occurrence have a significant impact on the mining technology and the rock mass stability [37-40].

\subsection{Qualitative Characteristics of Iron Ores}

In terms of mineral content, high-grade iron ores occurring on the territory of the Pivdenno-Bilozerske field are subdivided into martite ores (20-25\% of the deposit's balance reserves), hematite-martite together with martite-hematite ores $(75-80 \%$ of the balance reserves), and hematite ores (with an insignificant share of around 5\%). The average iron content in the balance reserves of the Pivdenno-Bilozerske field is $61.18 \%$, with the A, B, and $\mathrm{C}$ categories having $62.05,59.98,61.32 \%$ iron content, respectively. The average iron content is $62.07 \%$ in the developed reserves and $61.01 \%$ in the blocked-out reserves.

Of the total volume of the Pivdenno-Bilozerske ore reserves, martite ores are 30 and $28 \%$, respectively, disperse hematite-martite ores are 68 and $65 \%$, respectively, and disperse hematite ores are 2 and $7 \%$, respectively. The ore content in the ores of the PivdennoBilozerske field ranges from $48 \%$ at the boundary to $69 \%$. On the one hand, the quality of high-grade iron ores is determined by the content of iron and silica, and on the other hand, it is determined by lumpiness, which is important for assigning them to blast furnace or open hearth ores.

\subsection{Ore Deposit Uncovering and Preparing and Method of Mining}

The ore body has been uncovered through six vertical shafts. Main shaft No.1, main shaft No.2, and service shaft are located on the central mine shaft forming the central shaft group (CSG). The three shafts have been mined to a horizon of $1040 \mathrm{~m}$. Ventilation shafts have been mined to a horizon of $400 \mathrm{~m}$ on the northern and southern flanks of the field. Drainage shaft also used as a ventilation shaft has been mined to a horizon of $640 \mathrm{~m}$ 
in the hanging wall of the field. Currently, the shaft is in the stage of deepening. From the side of the footwall of the field, the ore body has been uncovered by level cross-cuts at the horizons of 400, 480, 640, 840, and $940 \mathrm{~m}$, driven from the central shaft group (Figure 5).

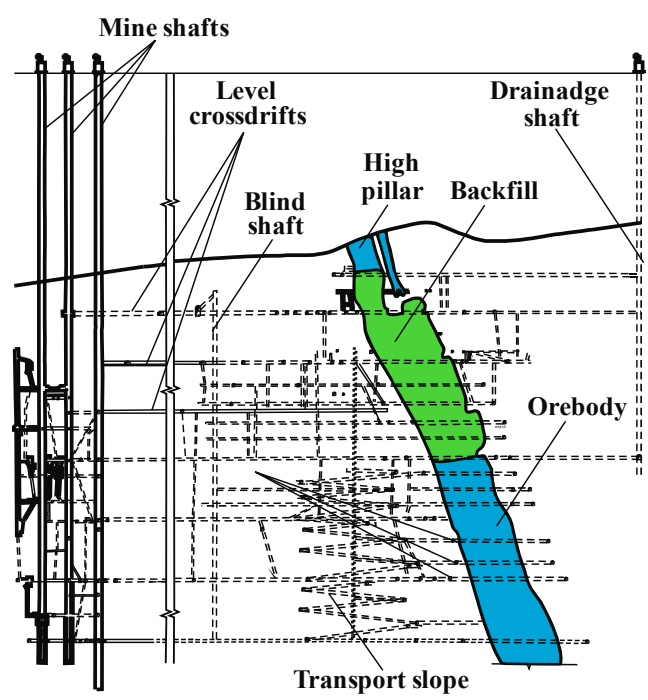

(a)

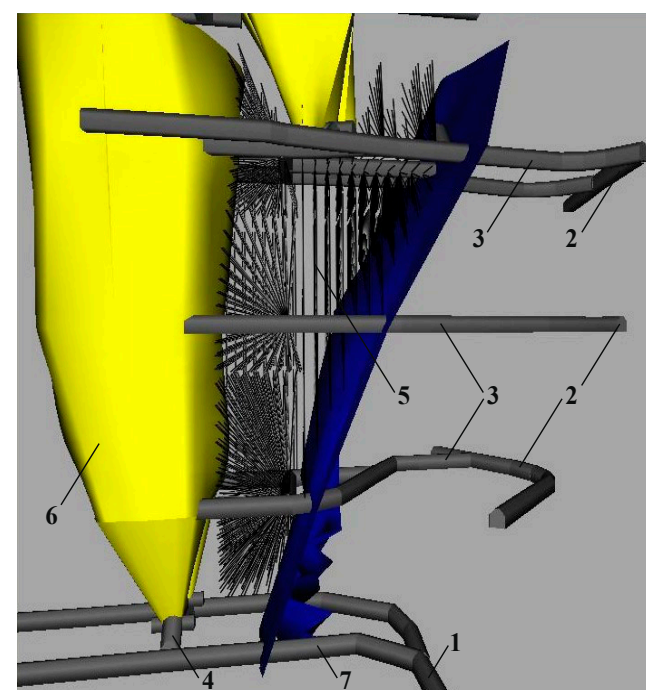

(b)

Figure 5. Method of mining used in the Pivdenno-Bilozerske field: (a) ore body uncovering and preparing; (b) mining method used: 1-haulage heading of the footwall; 2-sublevel headings of the footwall; 3-sublevel drill cross-cuts; 4-undercutting (trench) cross-cut; 5-well fan; 6-backfill; 7-haulage cross-cut.

The preparation of all horizons is in the development of cross-cuts and fringe drifts of both hanging wall and footwall, cross-cuts, and other mine workings. The drifts are driven at a distance of $20 \mathrm{~m}$ from the ore body, piercing them with cross-cuts at every $30 \mathrm{~m}$. The preparation scheme is effective for uncovering the thick steep deposits. The scheme provides the possibility of circular traffic and also improves ventilation conditions.

Level-chamber mining system is applied at the mine. The chambers are placed across the strike of ore deposits with ore breaking by vertical fans of deep wells and subsequent backfilling of mined-out area with fast-hardening mixtures. Such method of uncovering and mining is determined by the conditions of occurrence and geometric parameters of the Pivdenno-Bilozerske and Pereverzivske fields [19]. The system is used for 301-330, $340-400,400-480$, 480-640, and 640-840 m levels. The horizon of $840 \mathrm{~m}$ is a haulage one, under which the crushing facility is located. The chambers with their long sides are located across the strike in the form of a diamond or with inclined bottom. The size of the chamber $30 \mathrm{~m}$ along the strike and up to $60 \mathrm{~m}$ across the strike, and the chamber height coincides with the level height (i.e., 100-120 m). A positive experience of mining the ore reserves by double levels (chamber height is $180 \mathrm{~m}$ ) has been obtained in the northern part of the ore body in conditions of hard quartzite occurring in the hanging wall and footwall [41,42]. It should be noted that such a mining system is unconventional for underground ore mining because it is used mainly for the extraction of nonferrous metal ores due to the high cost of backfilling operations. The initial plan was to mine the deposit by overhead caving. However, as experience has shown, it is impossible to achieve a significant fall of water table on the Buchak horizon, and it was decided to mine with a chamber system, followed by backfilling the mined-out area with a hardening mixture.

The main chamber reserves are broken on compensating vertical or inclined cutoff stopes by fan systems of upward wells and downward wells with $105 \mathrm{~mm}$ diameter. They are drilled by NKR-100M drilling rigs and Simba H1352 self-propelled rigs from sublevel drill cross-cuts with upward fans of wells up to $35 \mathrm{~m}$ long. Cutoff stopes are cut into cutoff raising stopes by parallel upward and downward wells drilled from sublevel drill cross-cuts and cut ways using NKR-100M drilling rigs. Grammonite 79/21, AC-8, 
and packaged ammonite No.6ZhV are used as explosive materials to break the chamber reserves. Emulsion explosives of the UkrainitPP type have been used for mining since 2008 and for ore breaking since the end of 2013 [43]. The average output of ore by chambers is 25-30 thousand tons per month.

All the preparatory mine workings are driven using the drilling and blasting method using drilling rigs such as Axera and Boomer-252. Raising stopes are driven using a drilling rig such as Robbins 73RM-AC. Ore is mined using the VVDH-5 and PShV-6 vibration shakers as well as load haul dumpers with electric drive TORO-400E and LH-409E.

\subsection{Mining Schedule in Terms of Ore Body Area and Depth}

Because the thickness of ore deposits and intercalations vary, the Pivdenno-Bilozerske field has been divided into three sites: northern, central, and southern.

For mining the field, nine-chamber, six-chamber, and four-chamber sites combined into blocks are the most acceptable. The deposit is mined from the hanging wall to footwall. Chambers are diamond-shaped, close to natural, and ellipsoidal, which provides stability of chambers with increased dimensions and improves technical and economic indicators of the mining system. Stope operations are started with the southern site of the field. The mining procedure is adopted in such a way that a certain number of chambers, which could ensure the mine output, are simultaneously at the stage of stope operations. On average, almost 12-15 stopes are developed annually. The course of mining operations over the ore deposit area at $740 \mathrm{~m}$ horizon is shown in Figure 6 [36].

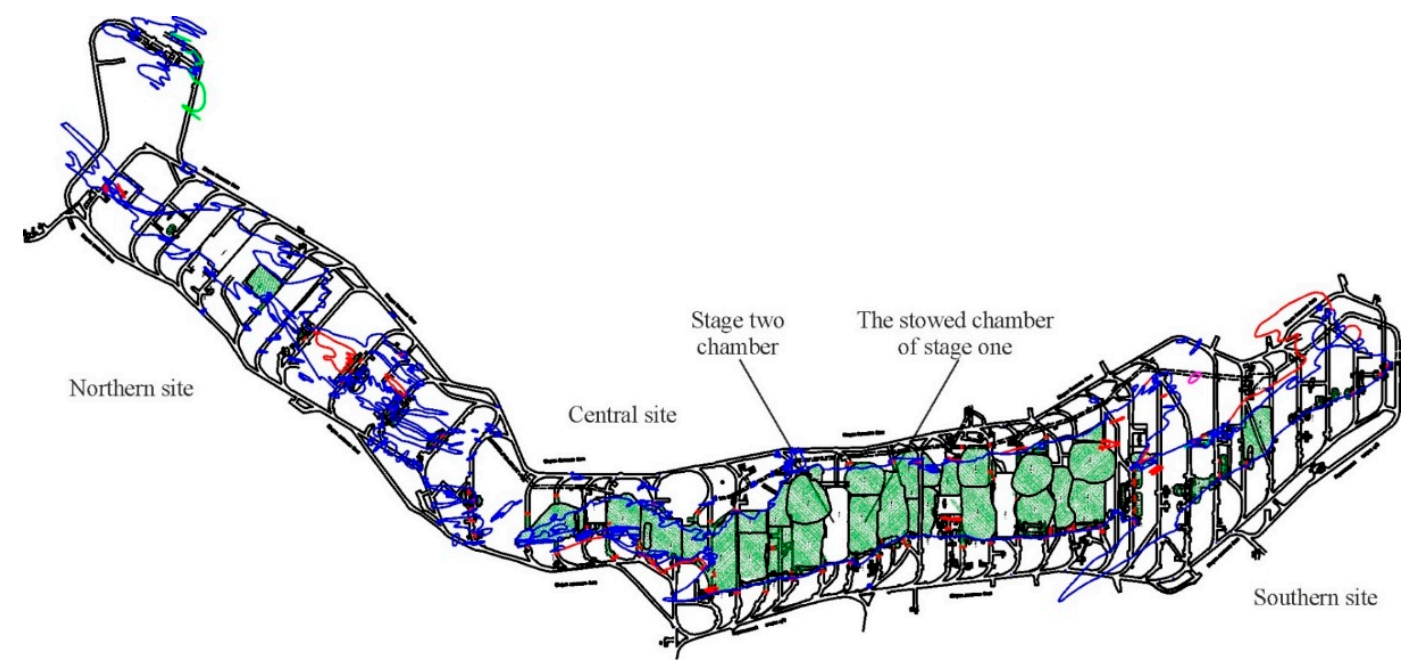

Figure 6. Schedule of stope and backfill operations along the ore deposit area (section of $740 \mathrm{~m}$ horizon) [36].

According to the ore deposit depth, the main mining operations take place at 640-740, 740-840, and 840-940 m levels. Capital mining operations are conducted to prepare reserves at the 940-1040 m level. As for the ore area, stope chambers are mined in groups through a pillar, which is equal to the chamber width [35,44]. Ore reserves are mined in the mine field at levels from the central part of the deposit to its flanks. The width of the chambers varies from 15 to $30 \mathrm{~m}$ depending on the deposit thickness and the stability of the ore and enclosing rocks. On an average, the geometry of the chambers is as follows: height is $80-120 \mathrm{~m}$, width is $15-30 \mathrm{~m}$, and length is $40-60 \mathrm{~m}$. The peculiarity is that in the central and southern parts of the field, 2-3 chambers are placed across the strike through the thickness of the deposit and one chamber is placed in its northern part.

The ore area on the southern flank at a depth of $253 \mathrm{~m}$ is 95 thousand $\mathrm{m}^{2}$, which is reduced by 5 thousand $\mathrm{m}^{2}$ with deepening for every $100 \mathrm{~m}$. On the northern flank, ore grade mineralization is much less than on the southern one, but it increases with depth. This condition makes it possible to compensate decreasing thickness of the southern flank with an increase in the depth of mining [45]. After mining the ore reserves, the chambers 
of the first stage are backfilled with a hardening mixture, and after three months, when the backfill acquires a standard strength, mining of the second stage chambers is started.

\section{Backfilling of the Mined-Out Area}

\subsection{Preparation of Backfill Mixture and Its Composition}

\subsubsection{Type of Backfilling the Mined-Out Area Used}

To prevent daylight surface subsidence as well as for waste disposal during mining of minerals, the method of backfilling the mined-out area is used [46]. Depending on the mining and geological conditions and requirements for the backfill mass, cemented rockfill (CRF) and cemented paste backfill (CPB) are used in the mines.

When filling underground cavities, the highest specific weight falls on the paste backfilling, which is widely used in mining of ore deposits in the leading countries of the world, such as the USA, Canada, Sweden, Japan, and Australia. Usually, the main components of cemented paste backfill are Portland cement (3-6\%), finely ground mine refuse, and water, while its compression strength is less than $1 \mathrm{MPa}[47,48]$. In addition, in the practice of mining ore deposits with backfilling, cemented rockfill is used, which consists of a binding material (maybe Portland cement, slag, or ash), a coarse fraction (crushed rocks or crushed stone), and water $[49,50]$. The strength of such a backfill mass is 5-10 MPa and more.

The Pivdenno-Bilozerske field is characterized by a significant depth of mining (600-900 m), the occurrence of unstable rocks, as well as a thick aquifer in the ore mass roof and large parameters of stope chambers (100-150 thousand $\mathrm{m}^{3}$ of volume). In the specified conditions, the strength of the paste backfill is insufficient, while an increase in the Portland cement proportion makes it more expensive. In addition, the absence of an iron ore beneficiation cycle (high quality of mined ores) and the absence of mine refuse makes it impossible to use paste backfilling. These mines prefer to use cemented rockfill. Therefore, today, at the PJSC Zaporizhzhia iron ore plant, a cemented rockfill is used, which consists of ground furnace granulated slag (rarely with the addition of cement), transported fluxing limestone waste, crushed rock refuse, and water.

\subsubsection{Variants of Backfill Mixtures Used in the Technological Cycle of Ore Mining}

During the Pivdenno-Bilozerske field operation, several formulations of cemented rockfill composition were used. The upper levels (400-480 m) were backfilled with different component mixtures. Initially, slag, cement, sand, and water were used. The backfill mass was formed with a strength of 2.5-4 MPa, which is insufficient for mining conditions. After 90 days, an increase in $\mathrm{SiO}_{2}$ content up to $60 \%$ resulted in the ore dilution, thereby complicating the process of steelmaking. Thus, it was decided to replace the sand with limestone from the Balaklava Mine Group. The limestone-based mixtures have proven high strength at the level of 6-9 MPa. Due to the gradual rise in transport costs, Balaklava limestone was replaced by Dokuchaevsk fluxing limestone, which is an accompanying component in the process of metallurgical treatment. However, for the complete backfilling of the chambers with inert materials or those containing useful components, significant volumes are required, which involves their mining at certain deposits and transportation to a mine backfilling complex. The total costs of backfilling operations increase significantly, which makes ore mining ineffective. To reduce costs, since 2001, the plant has been using crushed rock left from mining operations as a filler, adding it to the backfill mixture, thus reducing the cost of backfilling operations [51]. By adding coarse filler (rock) to the backfill mixture, it is possible to improve the rock mass strength from 4-5 to 6-7 MPa and reduce fluxing limestone dust consumption while lowering the negative effect of backfill material getting into the ore. The use of furnace slag as the basic binding material makes it possible to almost fully avoid the use of expensive Portland cement, with the exception of filling the bottom and sublevel mine workings of a chamber. 


\subsubsection{Achieved Modern Parameters of the Backfill Mixture}

Currently, furnace granulated slag from the metallurgical enterprise PJSC Zaporizhstal is used as a binding material to prepare a cemented rockfill mixture. Inert aggregate is represented by two types: (i) fluxing limestone waste from Dokuchaevsk flux and (ii) crushed rock refuse from dolomite plant combined with industrial water to produce a mixture [52]. Component composition and strength characteristics of the formed backfill mass in time are shown in Figure 7.

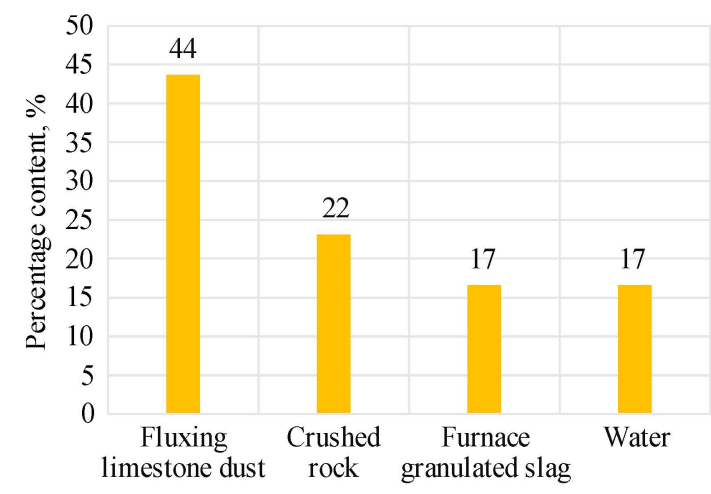

(a)

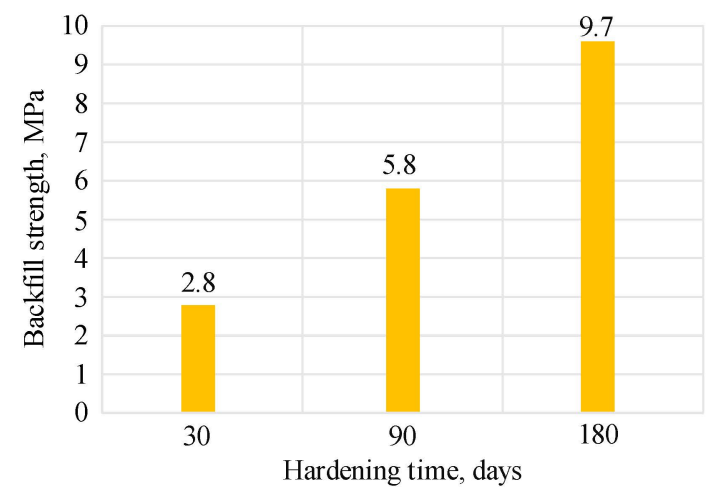

(b)

Figure 7. Characteristics of the backfill mixture: (a) composition; (b) strength characteristics.

In certain mining and geological conditions, specific weight of the furnace granulated slag can reach $25 \%$ of the total weight of the backfill mass components.

Annual output of backfill mixture is 1.0-1.2 million $\mathrm{m}^{3}$, and more than 2.0 million tons of mining and metallurgical waste is utilized in the underground space [53,54]. An important environmental aspect is that the volume of rock refuse required for backfilling operations is $20 \%$ more than the volume of rocks coming from drifting faces to waste dumps [55]. This means gradually intensifying the utilization of this method will result in a decrease in waste dump volume over time.

The backfilling complex for producing the mixture is located at the surface practically above the ore body, which reduces the distance of its transportation to the mined-out area. Basic facilities of the backfilling complex are shown in Figure 8.

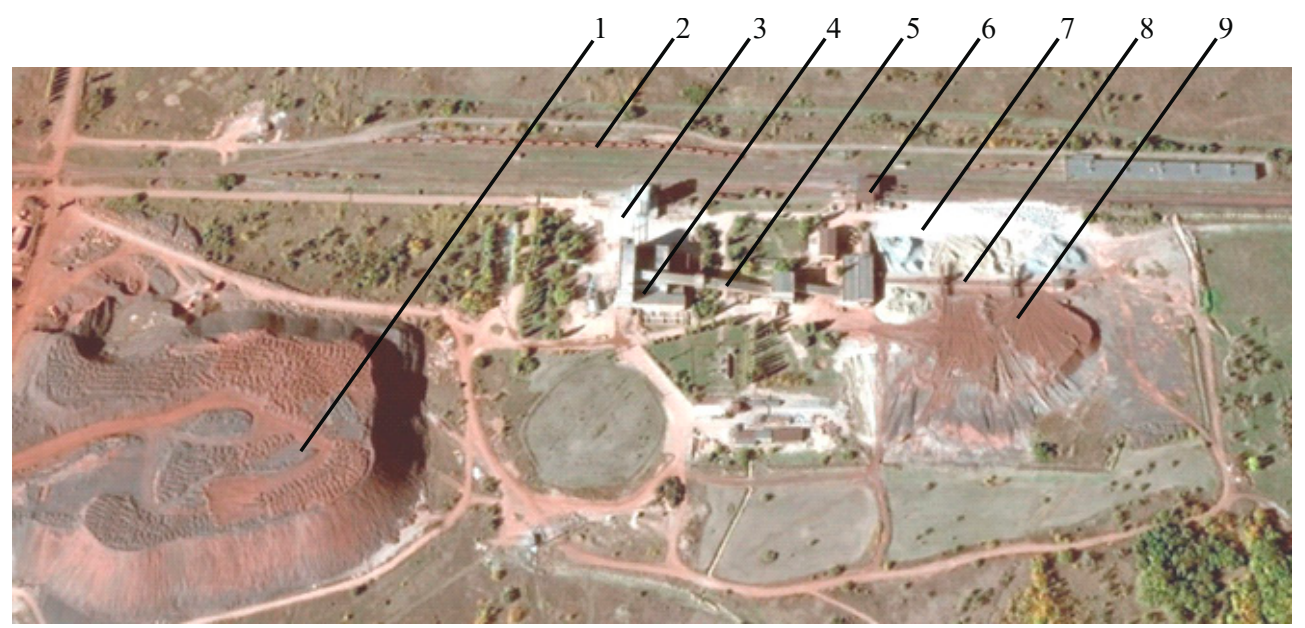

Figure 8. A view and basic facilities of surface backfilling complex: 1—waste dump; 2-railway; 3-cement storage tanks; 4-basic unit to produce backfill mixture; 5-conveyor gallery to the basic unit; 6-a point to discharge backfill materials; 7-storage location for furnace granulated slag; 8-overburden spreader; 9-flux waste storage. 
The complex includes a point for granular material discharge, storage yard, main building, and mixing tank. From the yard, slag and limestone flux are supplied through the separate conveyor lines to a set of machines of the main building. The rock is crushed to $200 \mathrm{~mm}$ fraction by means of a coarse crusher located on the territory of the waste dump. Then, it is loaded into wagons and fed to the main building of the backfilling complex. The furnace slag is ground in two grinding mills (with a capacity of $60 \mathrm{t} / \mathrm{h}$ each) by the wet grinding method. The fractional yield is $50-60 \%$ of particles with a coarseness of $0.074 \mathrm{~mm}$. At the outlet from the grinding mill, pulp density varies from 1.45 to $1.55 \mathrm{~g} / \mathrm{cm}^{3}$. All components are fed into a mixing tank of the S-892 type, mixed with water and fed through a backfill pipeline in the underground space. Research $[53,56]$ indicates that the fineness of grinding the $50-55 \%$ particles of the binding material with $0.074 \mathrm{~mm}$ coarseness cannot provide full manifestation of the furnace slag binding properties. With further increase in the slag dispersive capacity up to $92 \%$, significant strength increase (by 2.0-2.5 times) is observed, but the energy consumption for grinding also increases. The lack of energy-efficient technologies for high-performance fine grinding hinders the development of mechanical activation during backfilling operations.

\subsection{Transportation of Backfill Mixture}

The backfill mixture, prepared in the main building of the backfilling complex, is fed to the mixing tank, then piped to $480 \mathrm{~m}$ horizon through pipelines laid in inclined travel-ways and backfill wells. From the $480 \mathrm{~m}$ horizon, the mixture is supplied to $605 \mathrm{~m}$ horizon through pipelines laid in the raising stopes, and then the mixture moves by gravity under the action of hydrostatic pressure created in vertical pipelines through horizontal pipes laid in the drifts and cross-cuts from the side of the ore deposit hanging wall and enters from above into the chambers to backfill. To reduce pressure in the pipeline, damping loops with 200-300 $\mathrm{m}$ length is equipped at 325, 400, and $465 \mathrm{~m}$ horizons (Figure 9).

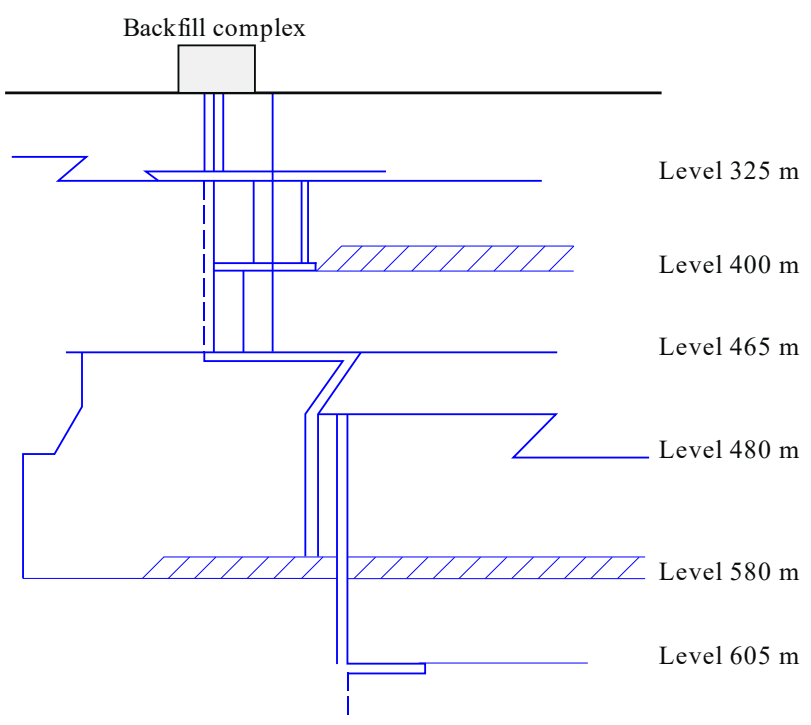

Figure 9. Scheme of the backfill pipelines.

If necessary, emergency backfill is discharged from horizontal and vertical pipelines into specially prepared chambers or into lifting raising stope. When the backfill mixture gets stuck in vertical wells, the BU-75BrE drilling rig is used to drill out wells plugged with backfill. The backfill wells are equipped with pipeline of 219,245 , or $273 \mathrm{~mm}$ in a diameter with the use of cast stone lining. To clean (wash) the backfill pipeline in a case of the backfill mixture blockages, a high-pressure washing pipeline with $110 \mathrm{~mm}$ diameter is laid parallel to it, connected to the backfill pipe inserts with a diameter of $50 \mathrm{~mm}$ every $30 \mathrm{~m}$. Critical velocity of the backfill mixture is $1 \mathrm{~m} / \mathrm{c}$. Its consistency is lost after $24 \mathrm{~h}$. 
The backfill mixture consistency is regulated depending on the transportation distance. In practice, consistency of a backfill mixture is within $10.5-12 \mathrm{~cm}$.

\subsection{Backfill Mass Formation}

The process of backfill mass formation in the stope chamber significantly affects the quality of ore reserves mined in contact with it as the bottom will be a roof of the chamber at the underlying level. Moreover, an artificial mass of 2000-3000 $\mathrm{m}^{2}$ area is being outcropped on the sides, which is exposed to the seismic impact from a huge blast. Before backfilling, the mined-out chamber should be isolated, which involves erection of the main and safety barricades adjoining the chamber. The barricades are necessary for water drainage and protection of mine workings from backfill mixture penetration. In the case of the sublevelchamber method of mining with the use of cemented rockfill, sublevel mine workings are mostly isolated by wooden barricades. The backfill mass formation throughout the height of a chamber and a view of a wooden barricade in the sublevel mine working are presented in Figure 10.

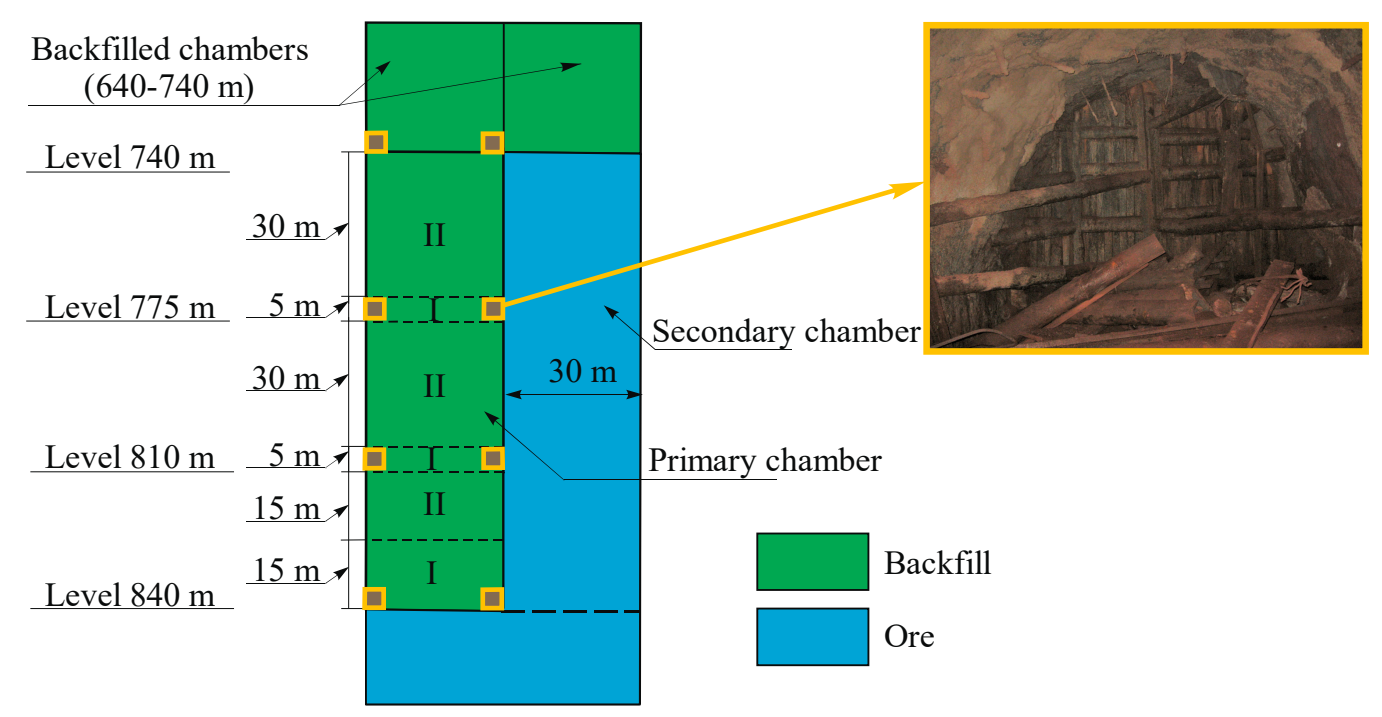

Figure 10. Technology of the backfill mass formation (level 740-840): I—strengthened backfill; II—standard backfill. The insert show a view of isolating wooden barricade in sublevel mine working.

Firstly, the pull holes are backfilled in the mined-out chamber. The height of backfilling of the first layer should not be less than $10 \mathrm{~m}$, while the content of a binding material (cement) should not be less than $10 \mathrm{~kg} / \mathrm{m}^{3}$. The backfill mixture should be of the stiffest consistency (water/cement ratio is reduced from 1.0 to 0.8 ) and supplied with a reduced intensity. When the bottom is filled, the mixture is not supplied to the chamber for $16-24 \mathrm{~h}$ until water stops draining. Then, the chamber is backfilled continuously up to the nearest barricade placed above.

After each layer is backfilled, the backfilling process should be stopped until full water draining from behind a barricade and due to the loss of consistency. When backfilling the level of sublevel barricades, the content of a cement as binding material should also be no less than $10 \mathrm{~kg} / \mathrm{m}^{3}$. Subsequently, after backfilling the last upper barricade, the chamber should be backfilled continuously until the level of backfilling reaches the roof of the chamber. The strength of backfilling the chamber bottom should be 10-12 MPa, and with further chamber erection, it should be 7-8 MPa [57]. The basic disadvantage of erecting the backfill mass is its stratification and heterogeneity, formed along the stope chamber height due to stoppages of the backfilling complex for draining water from behind barricades and a decrease in hydrostatic pressure on them resulting from the mass hardening. 
As a result of backfilling the mined-out areas at the upper levels (305-640 m) with hardening mixtures having low filtration properties after their hardening $\left(K_{f}=0.0001-\right.$ $0.0208 \mathrm{~m} /$ day), the underlying levels of ore reserves become isolated from heavily watered loose stratum by an artificial waterproof mass. This excludes further mass drainage, and as a result, the deep depression drainage funnel is prevented and underground water reserves are preserved to feed large intakes. The absence of mined-out areas on the overlying horizons significantly increases both stability and safety of the whole system of operating mine workings, preventing them from accidental large rock falls, which would be possible in the stopes that are not backfilled, as well as improving the tightness of the ventilation system to avoid losses through the mined-out area.

\subsection{Backfill Mass Stability and Dilution Indices}

Stope operations in the chambers of the second stage are performed either on the contact or fully surrounded by the artificial massif. Under these conditions, the strength of the artificial mass and its resistance to seismic impact during ore explosive blasting are very important from the viewpoint of rockfalls and broken ore dilution [58-62]. The 640-740 $\mathrm{m}$ level is the most representative from the viewpoint of backfill mass stability. More than $75 \%$ of ore reserves have already been mined out and blocked out there. In addition, a sufficient number of second-stage chambers has been mined out in order to assess the backfill mass stability $[63,64]$. According to the indicators of mining the chambers, the dilution degree of the ore mass mined from the chambers can be observed (Figure 11).

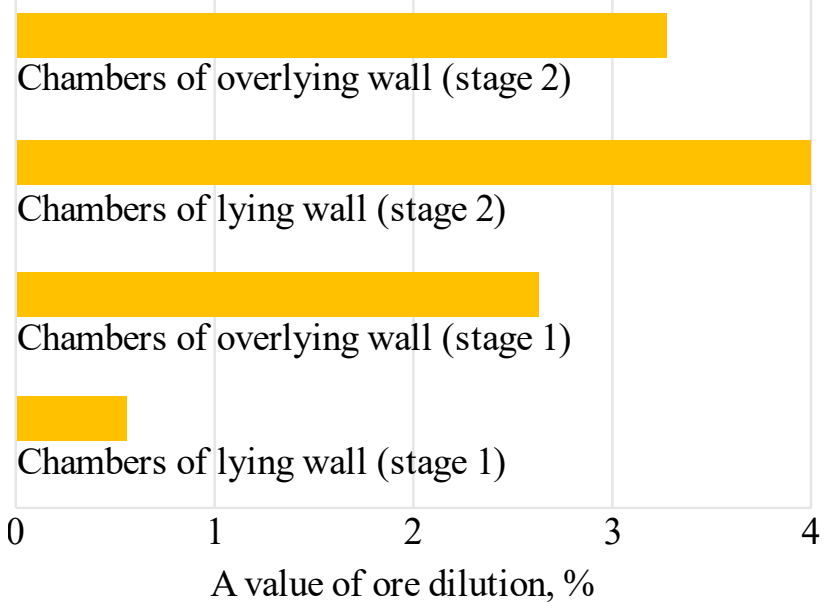

Figure 11. Averaged indices of ore dilution while mining chambers at the 640-740 m level.

In the chambers of the first stage of mining, semistable quartz-chlorite-sericite shale, which is located in the footwall, hanging wall, and in contact with the inclined chamber outcrop, collapses into the stope space. In this case, the rock strength, fracturing, and area of the inclined outcrop are of great importance. It is impossible to determine the dilution degree in the chambers of the second stage, located in the footwall and hanging wall, due to the contact with enclosing rocks. However, by the dilution intensity, it can be argued that this value is an order of magnitude higher in the chambers of the second stage than in the chambers of the first stage (Figure 12). 


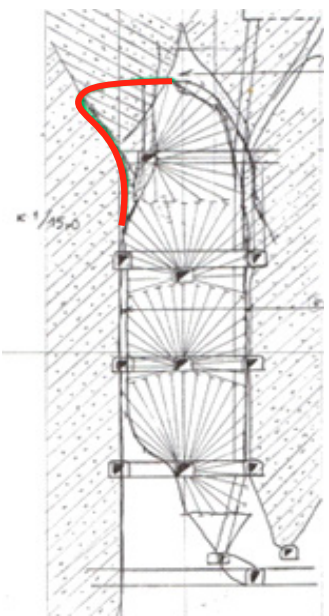

(a)

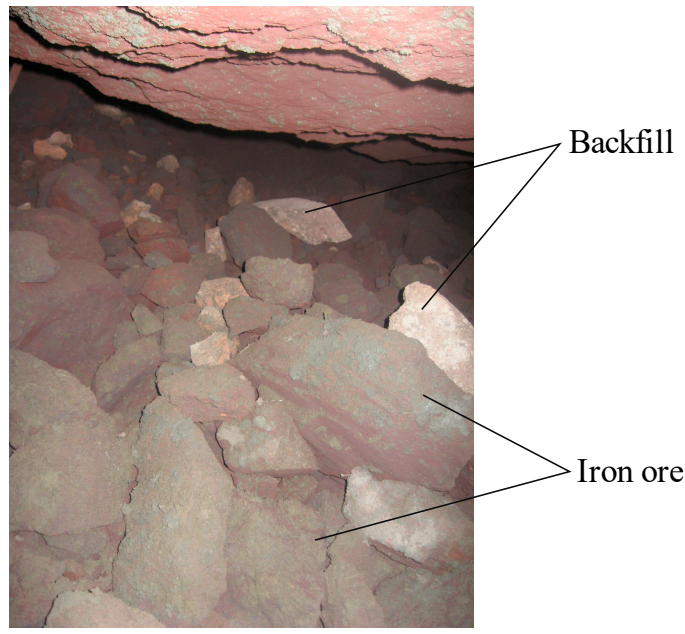

(b)

Figure 12. The disturbed stability of backfill mass: (a) one of the widespread areas of backfill mass failure; (b) dilution of ore when it is released from a chamber.

Based on the analysis results of mine documentation and underground surveys of stopes for 2006-2015, backfill failures and ore dilution were registered in at least 18 chambers. Moreover, roof, chamber walls, areas of chamber roof, and sides junction are the basic zones of backfill fall (Figure 12) $[59,65,66]$.

Dangerous tensile stresses, which occur on a backfill mass boundary, also intensify the destruction effect [67-71]. Moreover, semistable areas of vertical outcrops of a backfill mass make it heterogeneous and lead to stresses concentration on its boundary, orienting the directions of the backfill mass falls into the stope zone.

Despite the backfill mass failures, typical for mining systems with cemented rockfill, high technical and economic indicators have been achieved at the PJSC Zaporizhzhia iron ore plant in comparison with other underground mines that do not use it. Thus, the cost of ore mining is $9-11 \%$ lower than in the case of mining with caving, and the profitability of mining is $18-22 \%$. The costs for backfilling operations reach $15-19 \%$ of the production cost. The completeness of ore mining reaches up to $92 \%$. All this testifies to the high efficiency of backfilling the mined-out area with hardening mixtures. To the above, a reduction in payments for factors such as land loss, waste accumulation, and water pollution in the region with mineralized water can be added.

\section{Conclusions}

The use of backfilling with hardening mixtures when mining high-grade ores of the Pivdenno-Bilozerske field has made it possible to achieve a number of sustainable technological and environmental advantages:

- Exclude hollow mined-out areas of stopes and provide integrity and strength of backfilled areas and enclosing rocks while providing stability of the whole ore mass and safety of mine workings.

- Decrease vertical displacements of the mined-out ore mass and sedimentary stratum over the backfilled chambers, thereby decelerating the development of exfoliation of the whole rock mass and limiting the water inflow from aquifers to mine workings. Moreover, underground water reserves are preserved.

- Decrease both project and operational ore losses within interchamber pillars and floor pillars while reducing broken ore dilution in chambers and the possibility of rockfalls in the footwall and hanging wall of the deposit.

- Use dump rock as a component of a backfill mixture (up to $30 \%$ ) without reducing the calculated strength of the hardening mixture and reduce the cost of imported fillers 
and backfill materials. Partial use of the dump rock makes it possible to gradually clear the waste dump for further reclamation of the land plot used as a mine site.

- Improve the tightness of the mine ventilation system, reduce internal air leakage, and provide a stable and economical airing of the mine.

Along with the advantages of using the hardening backfill, a number of aspects should be noted that require improvement:

- In the process of backfill mass erection, a heterogeneous mass occurs with clearly defined stratification, which significantly affects the stability of vertical outcrops of the backfill mass.

- Binding material consumption is high. When filling the chambers of the first stage, it is crushed (its content is $25 \%$ in the specific weight of the mixture).

- The dilution of the broken chamber reserves may achieve $5 \%$ when mining out the chambers in contact with the backfill mass.

In such a way, the successful and very effective mining of a high-grade iron ore deposit with an iron content of more than $60 \%$ in difficult hydrogeological conditions has been achieved through the use of backfilling the mined-out area with hardening mixtures. This makes it possible to increase the production of iron ore for 50 years without damaging the daylight surface. Significant volumes of backfilling operations make it possible to annually dispose of large-tonnage waste from the mining and metallurgical industries in cavities, reducing the negative impact on the environment.

Despite the sufficiently strong backfill mass up to $10 \mathrm{MPa}$, destruction and falls of the backfill material into the broken ores are still observed in the process of mining the chambers, which leads to an increase in the dilution of the mined ore. Apparently, this is conditioned by the peculiarities of the stress-strain state formation of the multimodule rock mass consisting of ore, rocks, and backfill, which requires constant study and prediction. These aspects are especially relevant with a decrease in the level of mining operations where negative manifestations of rock pressure intensify. Therefore, the technologies of ore mining and backfilling operations as well as the backfill mixture formulations require constant improvement and optimization. Certainly, the experience of using the technology of backfilling operations when mining the Pivdenno-Bilozerske field, the peculiarities of which are covered in this paper, may be considered for use at a number of mines in the Kryvyi Rih iron ore basin, where the mining method of overhead caving is used.

Author Contributions: Conceptualization, O.B.; formal analysis, M.P. and V.L.; investigation, M.P. and S.Z.; data curation, S.Z.; writing-original draft preparation, K.S. and P.S.; writing-review and editing, M.P. and K.S.; visualization, V.L.; supervision, O.B.; All authors have read and agreed to the published version of the manuscript.

Funding: This study was carried out as part of the project "Belt and Road Initiative Centre for ChineseEuropean studies" and was funded by the Guangdong University of Petrochemical Technology.

Institutional Review Board Statement: Not applicable.

Informed Consent Statement: Not applicable.

Data Availability Statement: Data is contained within the article.

Acknowledgments: The team of authors expresses their gratitude to the reviewers for valuable recommendations that have been taken into account to significantly improve the quality of this paper.

Conflicts of Interest: The authors declare no conflict of interest.

\section{References}

1. U.S. Geological Survey. Mineral Commodity Summaries; U.S. Geological Survey: North Pole, AK, USA, 2020. [CrossRef]

2. Hellmer, S.; Ekstrand, J. The iron ore world market in the early twenty-first century-the impact of the increasing Chinese dominance. Miner. Econ. 2020, 25, 89-95. [CrossRef]

3. State Fiscal Service of Ukraine. Available online: http:/ / sfs.gov.ua (accessed on 9 November 2020). 
4. Haiko, H.; Saik, P.; Lozynskyi, V. The Philosophy of Mining: Historical Aspect and Future Prospect. Philos. Cosmol. 2019, 22, 76-90. [CrossRef] [PubMed]

5. Ursul, A.; Ursul, T. Environmental Education for Sustainable Development. Future Human Image 2018, 9, 115-125. [CrossRef]

6. Shatokha, V. The sustainability of the iron and steel industries in Ukraine: Challenges and opportunities. J. Sustain. Metall. 2015, 2, 106-115. [CrossRef]

7. $\mathrm{Fu}, \mathrm{Z}$. The mechanism of imported iron ore price in China. Mod. Econ. 2018, 9, 1908-1931. [CrossRef]

8. Peregudov, V.V.; Gritsina, A.E.; Dragun, B.T. Current state and future development of iron-ore industry in Ukraine. Metall. Min. Ind. 2010, 2, 145-151.

9. Khomenko, O.; Kononenko, M.; Myronova, I. Ecological and technological aspects of iron-ore underground mining. Min. Miner. Depos. 2017, 11, 59-67. [CrossRef]

10. Dryzhenko, A.; Moldabayev, S.; Shustov, A.; Adamchuk, A.; Sarybayev, N. Open pit mining technology of steeply dipping mineral occurences by steeply inclined sublayers. In International Multidisciplinary Scientific GeoConference SGEM2017, Science and Technologies in Geology, Exploration and Mining; SEGM: Bulgaria, Balkans, 2017. [CrossRef]

11. Pysmenniy, S.; Shvager, N.; Shepel, O.; Kovbyk, K.; Dolgikh, O. Development of resource-saving technology when mining ore bodies by blocks under rock pressure. E3S Web Conf. 2020, 166, 02006. [CrossRef]

12. Stupnik, N.; Kalinichenko, V.; Pismennij, S.; Kalinichenko, E. Features of underlying levels opening at "ArsellorMittal Kryvyic Rih" underground mine. New Dev. Min. Eng. 2015, 39-44. [CrossRef]

13. Petlovanyi, M.V.; Shustov, O.O.; Zubko, S.A.; Sherstiuk, I.A. The Natural Technogenic Massif Stability at Iron Ore Deposits Production. Submitted Research Work Nominated to be Awarded by the President of Ukraine in 2020. Available online: http:/ / www.kdpu-nt.gov.ua/en/node/310510 (accessed on 8 January 2021).

14. Russkikh, V.V.; Lapko, V.V.; Zubko, S.A. Development and adoption of new technical decisions for development of YuzhnoBelozerskoye ore deposit under difficult mining and geological conditions. Nauk. Visnyk Natsionalnoho Hirnychoho Universytetu 2012, 5, 34-38.

15. Khomenko, O.; Kononenko, M.; Petlyovanyy, M. Investigation of stress-strain state of rock massif around the secondary chambers. Progress. Technol. Coal Coalbed Methane Ores Min. 2014, 241-245. [CrossRef]

16. Bondarenko, V.; Kovalevs'ka, I.; Ganushevych, K. Progressive Technologies of Coal, Coalbed Methane, and Ores Mining; CRC Press: Boca Raton, FL, USA; Taylor \& Francis Group: London, UK, 2014; pp. 1-523. ISBN 978-0367576097. [CrossRef]

17. Khorolskyi, A.; Hrinov, V.; Kaliushenko, O. Network models for searching for optimal economic and environmental strategies for field development. Procedia Environ. Sci. Eng. Manag. 2019, 6, 463-471.

18. Azaryan, A.A.; Batareyev, O.S.; Karamanits, F.I.; Kolosov, V.O.; Morkun, V.S. Ways to Reduce Ore Losses and Dilution in Iron Ore Underground Mining in Kryvbass. Sci. Innov. 2018, 14, 17-24. [CrossRef]

19. Kuz'menko, A.; Furman, A.; Usatyy, V. Improvement of mining methods with hardening stowing of iron-ore deposits on big depths. New Tech. Technol. Min. 2010, 131-136. [CrossRef]

20. Petlovanyi, M. Influence of configuration chambers on the formation of stress in multi-modulus mass. Min. Miner. Depos. 2016, 10, 48-54. [CrossRef]

21. Pang, H.; Chen, C.; Xia, K.; Deng, Y.; Zhang, C.; Sun, C. A methodology based on strain analysis for identifying potential discontinuous deformation zones in sublevel caving mines. Eng. Geol. 2020, 279, 105872. [CrossRef]

22. Petlovanyi, M.; Malashkevych, D.; Sai, K.; Zubko, S. Research into balance of rocks and underground cavities formation in the coal mine flowsheet when mining thin seams. Min. Miner. Depos. 2020, 14, 66-81. [CrossRef]

23. Villegas, T.; Nordlund, E.; Dahnér-Lindqvist, C. Hangingwall surface subsidence at the Kiirunavaara Mine, Sweden. Eng. Geol. 2011, 121, 18-27. [CrossRef]

24. Lapshyn, O.Y.; Lapshyn, O.O.; Khudyk, M. The tragic consequences of the collapse of the earth's surface within the mining allotment of Ordzhonikidze mine. E3S Web Conf. 2020, 166, 3003. [CrossRef]

25. Zhao, X.; Zhu, Q. Analysis of the surface subsidence induced by sublevel caving based on GPS monitoring and numerical simulation. Nat. Hazards 2020, 103, 3063-3083. [CrossRef]

26. Parmar, H.; Yarahmadi, B.A.; Najafi, M. Impact of ground surface subsidence due to underground mining on surface infrastructure: The case of the Anomaly No. 12 Sechahun, Iran. Environ. Earth Sci. 2019, 78, 409. [CrossRef]

27. Xia, K.; Chen, C.; Lu, Z.; Yang, K.; Zheng, Y.; Pang, H.; Sun, C. Investigation of the ground movement due to underground mining at the Jinshandian Iron Mine in China. Environ. Earth Sci. 2019, 78, 715. [CrossRef]

28. Liu, G.; Li, N.A.; Yang, X.; Guo, L. Required strength estimation of a cemented backfill with the front wall exposed and back wall pressured. Int. J. Min. Miner. Eng. 2018, 9, 1-20. [CrossRef]

29. Li, X.; Wang, D.; Li, C.; Liu, Z. Numerical Simulation of Surface Subsidence and Backfill Material Movement Induced by Underground Mining. Adv. Civ. Eng. 2019, 1-17. [CrossRef]

30. Mineralni resursy Ukrainy. Derzhavnyi Informatsiinyi Heolohichnyi Fond Ukrainy. Available online: http:/ / minerals-ua.info/ (accessed on 24 April 2005).

31. Iron-ore Deposits of Ukraine. 2018. Available online: https://www.photoukraine.com/russian/articles?id=171 (accessed on 22 November 2020). 
32. Mykhailov, V.; Hrinchenko, O. Geology, Mining Industry and Environmental Problems of Ukraine. In Proceedings of the 12th International Conference on Monitoring of Geological Processes and Ecological Condition of the Environment, Kiev, Ukraine, 13-16 November 2018. [CrossRef]

33. Baklashov, I.A. Geomechanics. The basis of Geomechanics; MGTU: Moscow, Russia, 2004; pp. 1-208.

34. SNiP II-94-80. Underground Mining Workings; Stroiizdat, Gosstroi: Moscow, Russia, 1982; pp. 1-31.

35. Chistyakov, E.; Ruskih, V.; Zubko, S. Investigation of the geomechanical processes while mining thick ore deposits by room systems with backfill of worked-out area. Geomech. Process. Undergr. Min. 2012, 127-132. [CrossRef]

36. Petlovanyi, M.; Lozynskyi, V.; Zubko, S.; Saik, P.; Sai, K. The influence of geology and ore deposit occurrence conditions on dilution indicators of extracted reserves. Rud. Geol. Naft. Zb. 2019, 34, 83-91. [CrossRef]

37. Petlovanyi, M.; Lozynskyi, V.; Saik, P.; Sai, K. Predicting the producing well stability in the place of its curving at the under-ground coal seams gasification. E3S Web Conf. 2019, 123, 1019. [CrossRef]

38. Oryngozhin, Y.S.; Yeremin, N.A.; Metaxa, G.P.; Alisheva, Z.N. Underground uranium borehole leaching. News Natl. Acad. Sci. Repub. Kazakhstan Ser. Geol. Tech. Sci. 2020, 4, 62-69. [CrossRef]

39. Sai, K.; Malanchuk, Z.; Petlovanyi, M.; Saik, P.; Lozynskyi, V. Research of Thermodynamic Conditions for Gas Hydrates Formation from Methane in the Coal Mines. Solid State Phenom. 2019, 291, 155-172. [CrossRef]

40. Xia, K.; Chen, C.; Zheng, Y.; Zhang, H.; Liu, X.; Deng, Y.; Yang, K. Engineering geology and ground collapse mechanism in the Chengchao iron-ore mine in China. Eng. Geol. 2019, 249, 129-147. [CrossRef]

41. Russkikh, V.; Yavors'kyy, A.; Zubko, S.; Chistyakov, Y. Study of rock geomechanical processes while mining two-level interchamber pillars. Annu. Sci. Tech. Collect. Min. Miner. Depos. 2013, 149-152. [CrossRef]

42. Khomenko, O.; Kononenko, M.; Petlovanyi, M. Analytical modeling of the backfill massif deformations around the chamber with mining depth increase. New Dev. Min. Eng. 2015, 265-269. [CrossRef]

43. Kononenko, M.; Khomenko, O.; Savchenko, M.; Kovalenko, I. Method for calculation of drilling- and-blasting operations parameters for emulsion explosives. Min. Miner. Depos. 2019, 13, 22-30. [CrossRef]

44. Emad, M.Z.; Vennes, I.; Mitri, H.; Kelly, C. Backfill practices for sublevel stoping system. Mine Plan. Equip. Sel. 2014, $391-402$. [CrossRef]

45. Zaporozhskiy Zhelezorudnyy Kombinat. Produktsiya. Available online: http:/ /www.zgrk.com.ua / ?page=about\&t=product (accessed on 4 November 2020).

46. Li, L. A new concept of backfill design-Application of wick drains in backfilled stopes. Int. J. Min. Sci. Technol. 2013, 23, 763-770. [CrossRef]

47. Sivakugan, N.; Rankine, R.M.; Rankine, K.J.; Rankine, K.S. Geotechnical considerations in mine backfilling in Australia. J. Clean. Prod. 2006, 14, 1168-1175. [CrossRef]

48. Koupouli, J.F.; Belem, T.; Rivard, P.; Effenguet, H. Direct shear tests on cemented paste backfill-rock wall and cemented paste backfill-backfill interfaces. J. Rock Mech. Geotech. Eng. 2016, 8, 472-479. [CrossRef]

49. Basarir, H.; Bin, H.; Fourie, A.; Karrech, A.; Elchalakani, M. An adaptive neuro fuzzy inference system to model the uniaxial compressive strength of cemented hydraulic backfill. Min. Miner. Depos. 2018, 12, 1-12. [CrossRef]

50. Wu, J.; Feng, M.; Ni, X.; Mao, X.; Chen, Z.; Han, G. Aggregate gradation effects on dilatancy behavior and acoustic characteristic of cemented rockfill. Ultrasonics 2019, 92, 79-92. [CrossRef]

51. Petlovanyi, M.V.; Zubko, S.A.; Popovych, V.V.; Sai, K.S. Physicochemical mechanism of structure formation and strengthening in the backfill massif when filling underground cavities. (2020). Vopr. Khimii Khimicheskoi Technol. 2020, 6, 142-150. [CrossRef]

52. Kuz'menko, O.; Petlyovanyy, M.; Stupnik, M. The influence of fine particles of binding materials on the strength properties of hardening backfill. Annu. Sci. Tech. Collect. Min. Miner. Depos. 2013, 45-48. [CrossRef]

53. Petlovanyi, M.; Kuzmenko, O.; Lozynskyi, V.; Popovych, V.; Sai, K.; Saik, P. Review of man-made mineral formations accumulation and prospects of their developing in mining industrial regions in Ukraine. Min. Miner. Depos. 2019, 13, 24-38. [CrossRef]

54. Filonenko, O. Sustainable development of Ukrainian iron and steel industry enterprises in regards to the bulk manufacturing waste recycling efficiency improvement. Min. Miner. Depos. 2018, 12, 115-122. [CrossRef]

55. Kalybekov, T.; Rysbekov, K.; Sandibekov, M.; Bi, Y.L.; Toktarov, A. Substantiation of the intensified dump reclamation in the process of field development. Min. Miner. Depos. 2020, 14, 59-65. [CrossRef]

56. Petlovanyi, M.; Mamaikin, O. Assessment of an expediency of binder material mechanical activation in cemented rockfill. ARPN J. Eng. Appl. Sci. 2019, 14, 3492-3503.

57. Chistyakov, E.P.; Kulish, S.A.; Zubko, A.N.; Karapa, I.A.; Sakhno, A.V.; Kordis, Y.M.; Bednov, D.H. Tekhnologicheskaya Instrukciya Proizvodstva Zakladochnyh Rabot na Zaporozhskom Zhelezorudnom Kombinate; GP «NIGRI»: Krivoy Rog, Ukraine, 2010.

58. Aubertin, M. Interaction between backfill and rock mass in narrow stopes. Soil Rock Am. 2003, 1, 1157-1164.

59. Emad, M.Z.; Mitri, H.; Kelly, C. Effect of blast-induced vibrations on fill failure in vertical block mining with delayed backfill. Can. Geotech. J. 2014, 51, 975-983. [CrossRef]

60. Forster, K.; Milne, D.; Pop, A. Mining and rock mass factors influencing hangingwall dilution. Rock Mech. Meet. Soc. Chall. Demands 2007, 1361-1366. [CrossRef]

61. Urli, V.; Esmaieli, K. A stability-economic model for an open stope to prevent dilution using the ore-skin design. Int. J. Rock Mech. Min. Sci. 2016, 82, 71-82. [CrossRef] 
62. Malanchuk, Z.; Korniienko, V.; Malanchuk, Y.; Soroka, V.; Vasylchuk, O. Modeling the formation of high metal concentration zones in man-made deposits. Min. Miner. Depos. 2018, 2, 76-84. [CrossRef]

63. Kuzmenko, O.; Petlyovanyy, M.; Heylo, A. Application of fine-grained binding materials in technology of hardening backfill construction. Progress. Technol. Coal Coalbed Methane Ores Min. 2014, 465-469. [CrossRef]

64. Petlovanyi, M.V.; Ruskykh, V.V.; Zubko, S.A. Peculiarities of the underground mining of high-grade iron ores in anomalous geological conditions. J. Geol. Geogr. Geoecol. 2019, 28, 706-716. [CrossRef]

65. Sheshpari, M. Failures in Backfilled Stopes and Barricades in Underground Mines. Electron. J. Geotech. Eng. 2015, 20, 191-212.

66. Liu, Z.; Lan, M.; Xiao, S.; Guo, H. Damage failure of cemented backfill and its reasonable match with rock mass. Trans. Nonferr. Met. Soc. China 2015, 25, 954-959. [CrossRef]

67. Emad, M.Z. Numerical modelling approach for mine backfill. Sādhanā 2017, 42, 1595-1604. [CrossRef]

68. Kononenko, M.; Petlovanyi, M.; Zubko, S. Formation the stress fields in backfill massif around the chamber with mining depth increase. Min. Miner. Depos. 2015, 9, 207-215. [CrossRef]

69. Yang, P.; Li, L.; Aubertin, M. Stress ratios in entire mine stopes with cohesionless backfill: A numerical study. Minerals 2017, 7, 201. [CrossRef]

70. Piotr, M.; Łukasz, O.; Piotr, B. Modelling the Small Throw Fault Effect on the Stability of a Mining Roadway and Its Verification by In Situ Investigation. Energies 2017, 10, 2082. [CrossRef]

71. Abdiev, A.; Mambetova, R.; Abdiev, A.; Abdiev, S. Studying a correlation between characteristics of rock and their conditions. Min. Miner. Depos. 2020, 14, 87-100. [CrossRef] 